\title{
Effects of Thinning on Flow Peaks in a Forested Headwater Catchment in Western Japan
}

\author{
Haotian Sun ${ }^{1, *}$, Tamao Kasahara ${ }^{2}$, Kyoichi Otsuki ${ }^{3}$, Makiko Tateishi ${ }^{3}$, Takami Saito ${ }^{4}$ and \\ Yuichi Onda 5 \\ 1 Graduate School of Bioresource and Bioenvironmental Sciences, Kyushu University, \\ Fukuoka 811-2415, Japan \\ 2 Faculty of Agriculture, Kyushu University, Fukuoka 812-8581, Japan; tamao.kasahara@forest.kyushu-u.ac.jp \\ 3 Kasuya Research Forest, Kyushu University, Fukuoka 811-2415, Japan; \\ otsuki@forest.kyushu-u.ac.jp (K.O.); makikotateishi@gmail.com (M.T.) \\ 4 Institute for Space-Earth Environmental Research, Nagoya University, Nagoya 464-8601, Japan; \\ takamihappy@gmail.com \\ 5 Center for Research in Isotopes and Environmental Dynamics, University of Tsukuba, \\ Ibaraki 305-8572, Japan; onda@geoenv.tsukuba.ac.jp \\ * Correspondence: sunht1989@gmail.com; Tel.: +81-906-423-7965
}

Received: 25 April 2017; Accept: 18 June 2017; Published: 21 June 2017

\begin{abstract}
This study examined the changes in rainfall-runoff characteristics in the year prior to and after intensive thinning of 50\% in number in a steep headwater catchment, covered with 46-year-old Japanese cedar and cypress in western Japan. The magnitude of event peak flow, event quick flow, event water yield, and event response time did not change after thinning. Because $70 \%$ of rainfall events had multiple flow peaks, relationships between each flow peak and the rainfall just prior to that peak were also analyzed. The increases in accumulated quick flow, flow rise and flow drop were significant after thinning. The flow drop following each flow peak increased, and led to a lower initial flow in subsequent peaks, resulting in no increase in peak size. The flow peaks in events with over $30 \mathrm{~mm}$ rainfall amount and over $2 \mathrm{~mm} / \mathrm{h}$ average rainfall intensity showed significant increases in flow peak, flow rise, flow drop, and accumulated quick flow, which suggests that the catchment exhibited more shallow flow paths during large rainfall amounts after thinning. No changes were identified using event-based analysis, but changes in flow peaks were detected, which indicates the importance of examining all flow peaks when investigating rainfall-runoff characteristics of headwater catchments.
\end{abstract}

Keywords: forest thinning; headwater; flow peaks; event peak flow; conifer plantation

\section{Introduction}

In Japan, about $68 \%$ of the land surface is covered by forests on steep mountains [1]. Coniferous plantations, consisting largely of Japanese cypress and cedar, account for approximately $40 \%$ of this forested area [1]. It has been suggested that the decline in forest management over the past 30 years, linked to a recession-beleaguered forestry industry, has led to an increase in flood risk and soil erosion [2,3]. Because of the sparse understory vegetation beneath a dense canopy in abandoned plantations, soil erosion and overland flow on hillslopes can easily occur [4-7]. As the area of abandoned or non-managed plantation forest increases, thinning to increase tree growth [8] has emerged as a forest management tool to prevent environmental problems, such as erosion and floods [3]. After thinning, improved light conditions under the forest canopy can increase the growth of understory vegetation [9]. This growth can improve forest floor conditions by altering infiltration capacities and potential for shallow flow pathways [10]. 
Various studies have been undertaken to examine the effects of forest thinning on event flow [11-14]. However, their findings regarding changes in event flow characteristics have been inconsistent [15-20].

Some studies have shown that forest thinning increases event peak flow [15-17]. For example, after selective thinning of $67 \%$ of the timber volume, the event peak flow of small storms was increased by $111 \%$ in a 424 ha catchment, with gentle slopes covered by redwood (Sequoia sempervirens (D. Don) Endl.) and Douglas fir (Pseudotsuga menziesii (Mirb.) Franco), located in Northwestern California, USA, under a Mediterranean climate [15]. Likewise, random thinning of $84 \%$ ( $74 \%$ of basal area) increased event peak flows by $50 \%$ in an 80 ha catchment covered by jarrah (E. marginata Don ex Smith) and marri (E. calophylla Lindl.) in southwestern Western Australia, under a climate having high winter rainfall, and hot dry summers [16]. Selective thinning of 70\% trees (69\% basal area) increased peak flow rates by $40 \%$ in a 60 ha catchment covered by 15-year-old loblolly pine (Pinus taeda L.) in North Carolina, USA, under a maritime temperate climate [17]. In contrast, other studies have observed no changes in event peak flow after thinning [18-20]. Thinning of $6 \%$ of the timber volume resulted in the event peak flow being unchanged in a 27.4 ha steep catchment covered with Japanese cedar (Cryptomeria japonica), Japanese cypress (Chamaecyparis obtusa), red pine (Pinus densiflora), and oak (Quercus spp.) in Kochi Prefecture, Japan, under a warm to temperate rainy climate [18]. Catchments that underwent thinning operations with high thinning percentages also showed no changes to their event peak flow $[19,20]$. For example, thinning of $58.3 \%$ ( $43.2 \%$ of basal area) in a 0.35 ha steep headwater catchment, covered by Japanese cypress (Chamaecyparis obtusa) in Mie Prefecture, Japan, under a moist temperate climate $(0.70-1.00 \mathrm{~m} / \mathrm{m})$, did not affect event peak flow [19]. After $8.9-75.1 \%$ thinning of the basal area, no changes in event peak flow were detected in six catchments having gentle slopes $(0.02-0.26 \mathrm{~m} / \mathrm{m})$, covered mainly by loblolly pine (Pinus taeda L.), with a lesser component of mixed hardwoods, in Mississippi, USA, under a humid subtropical climate [20].

The event peak response time, which is calculated as the time between the rainfall peak and event highest flow peak, has been reported to decrease after thinning [15,21]. After logging and road construction, shorter event peak response times with steeper falling limbs were found; this is despite no changes in event peak flow in two catchments with areas of 424 ha and 473 ha [22]. In the six headwater catchments, where no event peak flow changes were observed after thinning of $8.9-75.1 \%$ of the basal area, the event peak response times were shortened in three catchments, associated with intense disturbance of the forest floor; whereas no changes in the event peak response times were observed in the other three catchments, associated with minimum disturbance of the forest floor [20].

Previous studies on the effect of thinning on rainfall-runoff processes have tended to examine only the characteristics of event peak flow, which is the highest peak of any one event [15-20]. However, headwater catchments generally generate multiple flow peaks, directly responding to rainfall even during a single event; while down-stream larger catchments do not [23,24]. Therefore, investigating all the flow peaks in headwater catchments is important to understanding changes in rainfall-runoff processes after thinning. This information provides deeper insights to the considerable effects of rainfall on sediment transport [25], nutrient transport [26], and stream morphology [27].

In this study, $50 \%$ of the trees in a steep headwater catchment, covered with 46-year-old Japanese cypress and cedar, were thinned. Our objective was to examine the effects of thinning in a cypress and cedar tree plantation on rainfall-runoff characteristics. We hypothesized that the event peak flow and flow peaks would not be altered after thinning of $50 \%$ of the trees in this tree plantation. We undertook a single-catchment study and compared rainfall-runoff characteristics for similar rainfall periods in the year prior to and after the thinning exercise.

\section{Site Description}

The Yayama Experimental Catchment (YEC) study site is a 2.98 ha headwater catchment. It is located in Fukuoka Prefecture $\left(33^{\circ} 31^{\prime} \mathrm{N}, 130^{\circ} 39^{\prime}\right.$ E) on the island of Kyushu, Japan (Figure 1). The elevation of the catchment ranges from 305 to $406 \mathrm{~m}$. The entire catchment is underlain by 
granite and its topography comprises steep slopes and narrow valley floors. The channel is incised in a section, where the channel gradient is steep; the mean hillslope gradient is $0.81 \mathrm{~m} / \mathrm{m}$, and the mean stream gradient is $0.37 \mathrm{~m} / \mathrm{m}$. According to a field survey by a drilling company [28], the deeply weathered granite bedrock has a thickness of $13.7 \mathrm{~m}$ in the riparian area and $17.5 \mathrm{~m}$ on the hillslope. The riparian groundwater table is $2.5 \mathrm{~m}$ below the valley floor during the driest period and reaches ground level during the rainy season. The hillslope groundwater table measured at an upslope location is higher than the riparian groundwater table; it is $15 \mathrm{~m}$ below ground level during the driest period and reaches to $7 \mathrm{~m}$ below ground level during the rainy season. Four distinct soil layers within the catchment are recognized, based on Dixfield-Marlow-Brayton general soil associations. The soil has a thickness of 70-100 cm, with high porosity (65\%), and a high saturated hydraulic conductivity of $3.24 \mathrm{~mm} / \mathrm{min}[28,29]$.

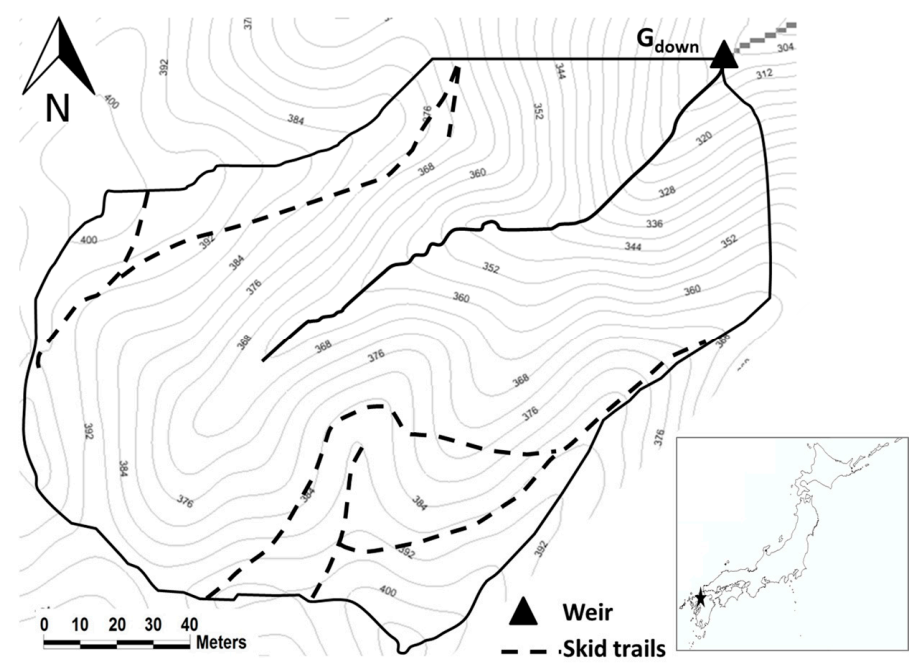

Figure 1. Map of the study site in the Yayama experimental catchment (YEC).

The average annual rainfall for the area is $2084 \mathrm{~mm}$ (1981-2010), based on rainfall data obtained from the nearby Uchino weather station $\left(33^{\circ} 32^{\prime} \mathrm{N}, 130^{\circ} 38^{\prime} \mathrm{E} ; 80 \mathrm{~m}\right.$ a.s.1.), maintained by the Ministry of Land, Infrastructure, Transport, and Tourism. Precipitation falls occasionally as snow in January and February, and melts in early February. The rainy season is from mid-June to early July. Typhoon season is from mid-August to early September. Japanese cypress (Chamaecyparis obtusa Sieb. et Zucc.) and Japanese cedar (Cryptomeria japonica D. Don), planted in 1969, covered the catchment with a density of 1324 trees/ha and accounted for $67 \%$ and $33 \%$ of the entire stock before thinning in 2012, respectively [30].

\section{Material and Methods}

\subsection{Field Measurements}

A single-catchment study was undertaken at the YEC from January 2011 to December 2013. Data from 2011 were used for the pre-thinning analysis, while those from 2013 were used for the post-thinning analysis. About $50 \%$ of the trees in the YEC were qualitatively thinned using chainsaws and removed during January-March 2012. The flow data for the rainy season of 2012 were not recorded because of equipment failure. Therefore, data for 2012 were not included in this study.

Rainfall was collected at a weather station located about $185 \mathrm{~m}$ southeast of the catchment, at an elevation of $390 \mathrm{~m}$. A $0.5 \mathrm{~mm}$ tipping bucket rain gauge (TK-1; Takeda Keiki, Tokyo, Japan) was used, with data collected at 10 min intervals. An inter-storm period of at least $6 \mathrm{~h}$ without rain was used to identify rainfall events. Furthermore, only events with rainfall amounts of $\geq 5 \mathrm{~mm}$ were selected for analysis. 
A stream gauging station $\left(\mathrm{G}_{\text {down }}\right)$, consisting of a V-notch weir and a Parshall flume, was installed at the outlet of the catchment (Figure 1). The V-notch gauge was used to monitor low flow, while the Parshall flume monitored high flow. The stage height was monitored at $10 \mathrm{~min}$ intervals in the V-notch weir and at 5 min intervals in the Parshall flume, using WT-HR water level loggers (TruTrack, Christchurch, New Zealand). Visual stage height readings and direct measurement of discharge were taken weekly during the wet season from June to July and bi-monthly during the remainder of the year to check and correct the stage—-discharge relationship.

\subsection{Flow Separation}

The quick flow component of the streamflow was separated using the digital filter method, proposed by Eckhardt [31]. The maximum baseflow index (BFImax) in the digital filter was estimated using the backwards filtering method, proposed by Collischonn and Fan [32]. The quick flow was terminated when the calculated baseflow equaled the actual flow. This method considers the geological characteristics of the catchment in the calculations, and it has been successfully applied in several studies in which hydrograph separation has been performed [33,34]. An event was defined as the beginning of rainfall to the end of its quick flow period, or the beginning of next rainfall event, when the quick flow was ongoing.

\subsection{Definition of Event Flow and Flow Peaks}

The parameters of the event flow in this study were defined as follows. The event peak flow was the highest flow in a single event (Figure 2a, A). The event peak response time was calculated as the time between the rainfall peak and the event highest flow peak (Figure 2a, B). Event water yield and event quick flow were calculated as the integration under the flood event hydrograph.

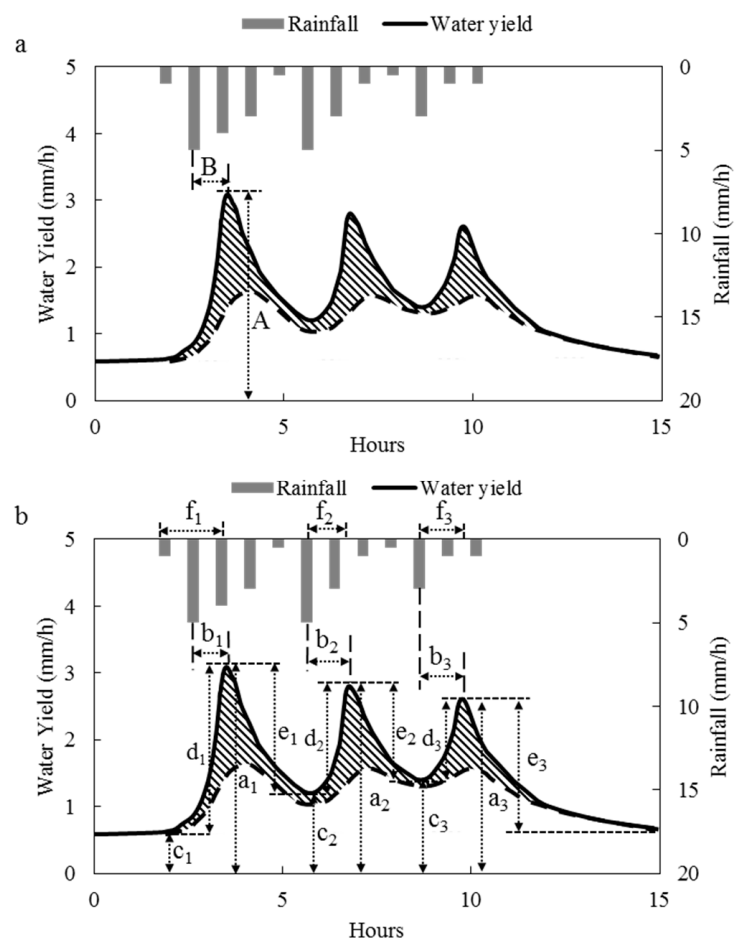

Figure 2. Schematics diagram of an event with 3 flow peaks showing (a) event flow characteristics: A. event peak flow $(\mathrm{mm} / \mathrm{h})$, B. event peak response time $(\mathrm{h})$, and shaded area which indicates event quick flow; and (b) flow peak characteristics: $a_{i}$. flow peak $(\mathrm{mm} / \mathrm{h}), \mathrm{b}_{i}$. flow peak response time $(\mathrm{h}), \mathrm{c}_{i}$. initial flow $(\mathrm{mm} / \mathrm{h}), \mathrm{d}_{i}$. flow rise $(\mathrm{mm} / \mathrm{h}), \mathrm{e}_{i}$. flow drop $(\mathrm{mm} / \mathrm{h}), \mathrm{f}_{i}$. accumulated rainfall $(\mathrm{mm})$, and shaded area which indicates accumulated quick flow for each peak. 
The parameters of flow peak in this study were defined as follows. Flow peaks were defined as all the peaks for a single event (Figure $2 b, a_{i}$ ). The flow peak response time was calculated as the time between the rainfall peak and the corresponding flow peak (Figure $2 b, b_{i}$ ). The initial flow was defined as the flow at the beginning of the rise in the hydrograph for the corresponding flow peak (Figure $2 \mathrm{~b}, \mathrm{c}_{i}$ ). To exclude the effect of the rainfall prior to this rise in the hydrograph, we calculated the flow rise from the initial flow to the corresponding flow peak (Figure $2 b, d_{i}$ ). We also calculated the flow drop from the flow peak to the end of the falling limb, which coincides with the next initial flow, when succeeding flow peak exists (Figure $2 \mathrm{~b}, \mathrm{e}_{i}$ ). Accumulated rainfall was calculated as the sum of the rainfall for the period between the initial flow and the corresponding flow peak (Figure $2 b$, $\mathrm{f}_{i}$ ). Accumulated quick flow was calculated as the sum of the quick flow for the period between the initial flow and the subsequent initial flow or the end of the falling limb (Figure 2b, shaded area).

\subsection{Statistical Analysis}

Streamflow data do not usually follow the probability distributions on which many statistical methods are based. Therefore, application of nonparametric statistical methods is required. Here, the Mann-Whitney $U$ test (u-test), which is sensitive to differences in the mean $\left(\mathrm{H}_{0}\right.$ : mean ranks of runoff values of two classes in the same group are similar), was applied [35]. Analysis of covariance (ANCOVA) was applied to assess the effect of thinning on event peak flow, event quick flow, event water yield, flow peak, accumulated quick flow, flow rise, and flow drop parameters.

\section{Results and Discussion}

The annual precipitation in YEC during the two-year monitoring period was similar, comprising $2341 \mathrm{~mm}$ in 2011, and $2322 \mathrm{~mm}$ in 2013. At the nearby Uchino weather station, the annual precipitation during this two-year monitoring period also was similar, being $2397 \mathrm{~mm}$ in 2011 and $2480 \mathrm{~mm}$ in 2013 . For the years before the monitoring periods, the annual precipitation had similar values of $2632 \mathrm{~mm}$ in 2010 and 2547 in 2012. The mean annual precipitation from 1981 to 2011 at the nearby Uchino weather station was $2098 \mathrm{~mm}( \pm 387 \mathrm{~mm})$. These data show that the study period covered relatively wet years in the region. The similarity in precipitation during the monitoring period and the years before enables us to perform event flow analysis. There were 67 and 64 events with rainfall amounts of $\geq 5 \mathrm{~mm}$, before and after thinning, respectively, which were concentrated between June and September (Figure 3). The sum of the event water yield was $608 \mathrm{~mm}$ before thinning in 2011, and $687 \mathrm{~mm}$ after thinning in 2013.
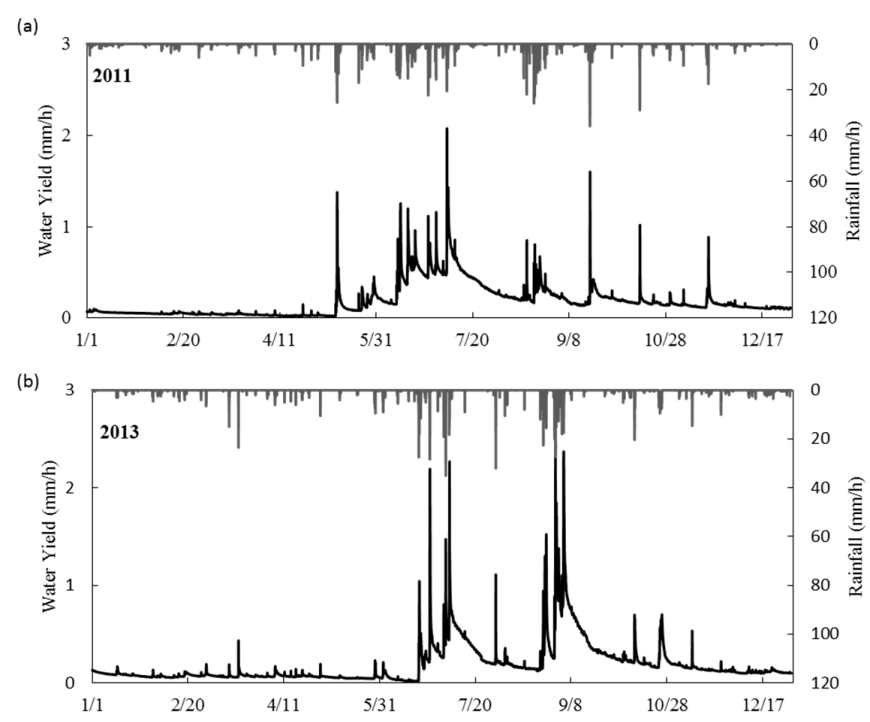

Figure 3. Hydrograph and hyetograph in the YEC in (a) 2011 and (b) 2013. 


\subsection{Changes in Event Flow after Thinning}

The rainfall-runoff characteristics before and after thinning were firstly compared at event flow basis. The changes in event flow after thinning were examined based on the relationships between rainfall amount and event peak flow, event quick flow and event water yield (Figure 4). There were no differences in the relationships between rainfall amount and event peak flow (ANCOVA: $p=0.45$ ), event quick flow (ANCOVA: $p=0.14$ ) and event water yield (ANCOVA: $p=0.93$ ), for events documented before and after thinning.
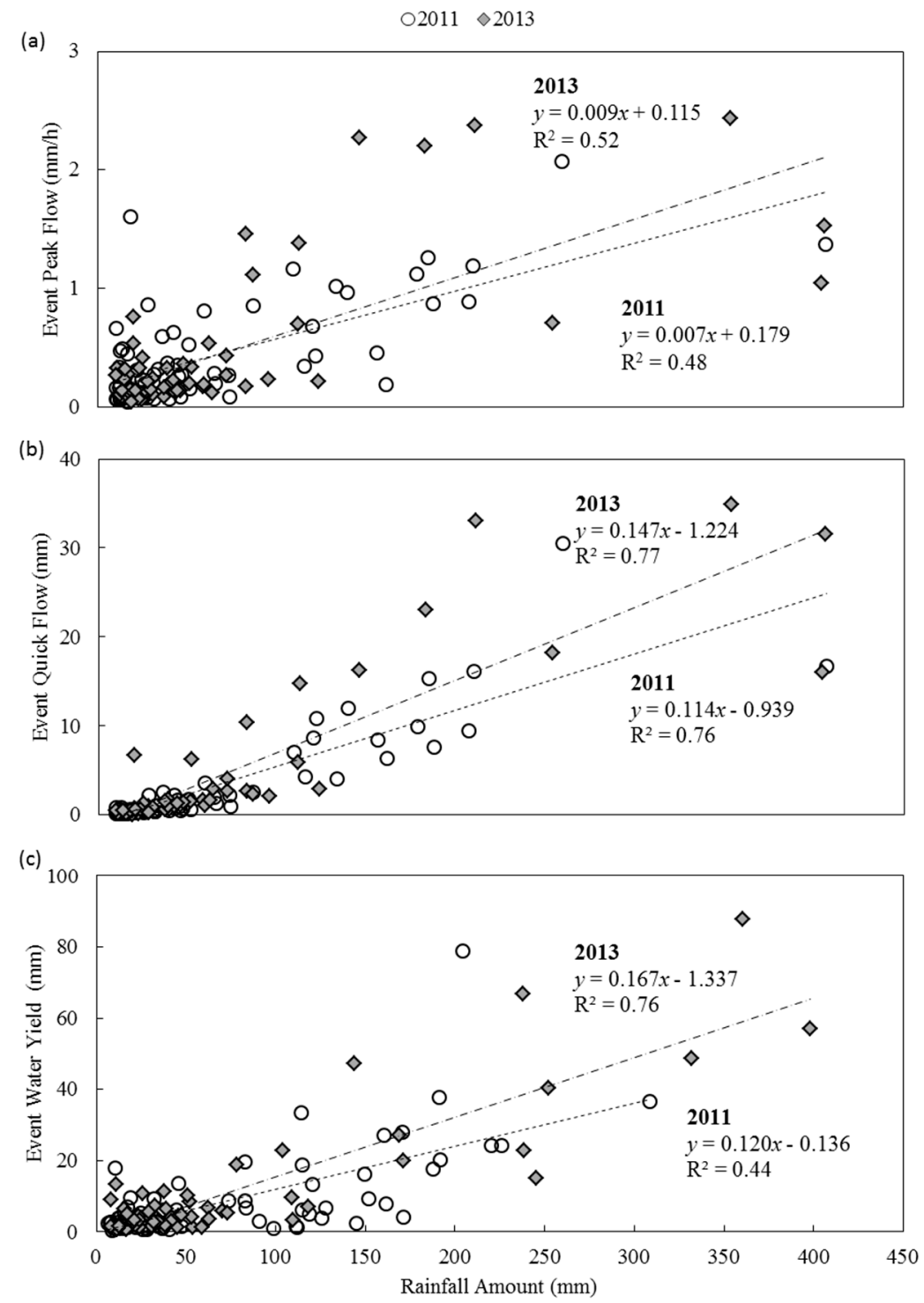

Figure 4. Rainfall amount in relation to (a) event peak flow; (b) event quick flow; (c) event water yield for all the events in 2011 and 2013.

To explore the changes in event flow after thinning for similar rainfall event size, we categorized the events into four groups. We selected a rainfall amount of $30 \mathrm{~mm}$ and an average rainfall intensity of $2 \mathrm{~mm} / \mathrm{h}$ as the criteria with which to divide the events, because $46 \%$ and $47 \%$ of events recorded before and after thinning had rainfall amount $<30 \mathrm{~mm}$ and average rainfall intensity $<2 \mathrm{~mm} / \mathrm{h}$ (Figure 5). The event flow characteristics of each group are summarized in Table 1 . The number of events within each group was similar before and after thinning, which allowed us to examine changes in event flow (Table 1). 


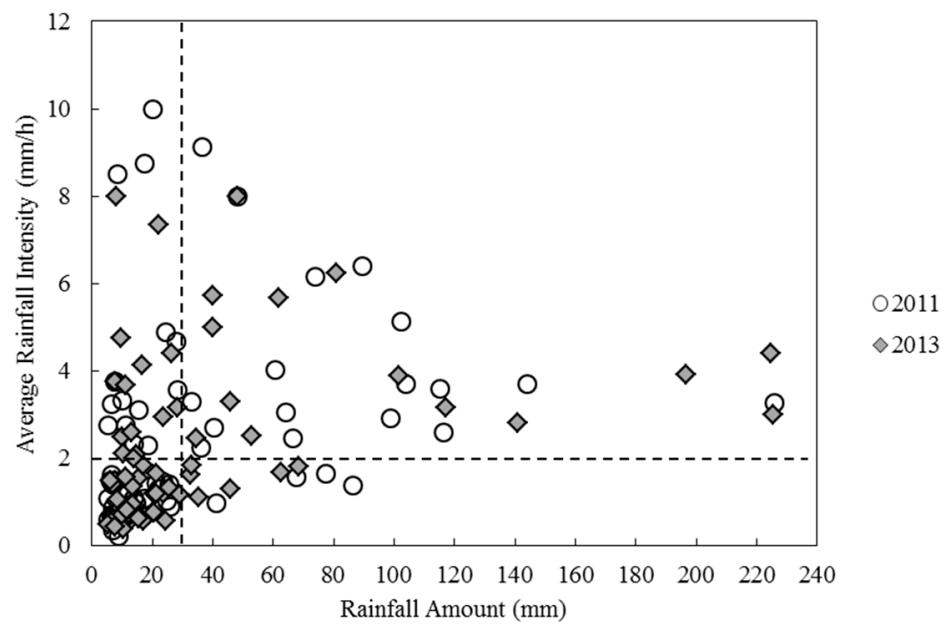

Figure 5. Scatter plot of rainfall amount $(\mathrm{mm})$ and average rainfall intensity $(\mathrm{mm} / \mathrm{h})$ for all the events in 2011 and 2013.

Table 1. Summary of event flow characteristics in 2011 (Before) and 2013 (After); $p$-values are listed in the $\mathrm{u}$-test and ANCOVA results section.

\begin{tabular}{|c|c|c|c|c|c|c|c|c|c|}
\hline \multirow{2}{*}{\multicolumn{2}{|c|}{$\begin{array}{c}\text { Rainfall Amount (mm) } \\
\text { Average Rainfall Intensity (mm/h) }\end{array}$}} & \multicolumn{4}{|c|}{$<30$} & \multicolumn{4}{|c|}{$\geq 30$} \\
\hline & & \multicolumn{2}{|c|}{$<2$} & \multicolumn{2}{|c|}{$\geq 2$} & \multicolumn{2}{|c|}{$<2$} & \multicolumn{2}{|c|}{$\geq 2$} \\
\hline \multicolumn{2}{|c|}{ Group Number } & \multicolumn{2}{|c|}{1} & \multicolumn{2}{|c|}{2} & \multicolumn{2}{|c|}{3} & \multicolumn{2}{|c|}{4} \\
\hline \multicolumn{2}{|l|}{ Years } & 2011 & 2013 & 2011 & 2013 & 2011 & 2013 & 2011 & 2013 \\
\hline \multicolumn{2}{|c|}{ Number of events } & 31 & 30 & 15 & 14 & 4 & 6 & 17 & 14 \\
\hline \multirow{2}{*}{$\begin{array}{l}\text { Event rainfall } \\
\text { amount }(\mathrm{mm})\end{array}$} & Average & 12.6 & 14.0 & 12.9 & 15.4 & 68.1 & 46.3 & 85.6 & 100.8 \\
\hline & Median & 10.5 & 12.0 & 14.0 & 13.5 & 72.5 & 40.8 & 74.0 & 71.5 \\
\hline \multirow{2}{*}{$\begin{array}{l}\text { Event peak } \\
\text { flow }(\mathrm{mm} / \mathrm{h})\end{array}$} & Average & 0.17 & 0.17 & 0.46 & 0.23 & 0.48 & 0.37 & 0.85 & 1.23 \\
\hline & Median & 0.16 & 0.13 & 0.33 & 0.21 & 0.43 & 0.18 & 0.86 & 1.07 \\
\hline \multirow{2}{*}{ Event quick flow (mm) } & Average & 0.4 & 0.9 & 0.8 & 0.6 & 8.0 & 4.2 & 8.6 & 14.4 \\
\hline & Median & 0.4 & 0.4 & 0.5 & 0.4 & 9.6 & 2.7 & 7.0 & 13.2 \\
\hline \multirow{2}{*}{$\begin{array}{l}\text { Event water } \\
\text { yield }(\mathrm{mm})\end{array}$} & Average & 4.0 & 4.6 & 4.9 & 3.4 & 21.7 & 12.3 & 18.9 & 30.5 \\
\hline & Median & 2.1 & 3.1 & 3.8 & 1.7 & 22.8 & 7.2 & 13.3 & 22.8 \\
\hline \multirow{2}{*}{$\begin{array}{l}\text { Event peak } \\
\text { response time }(\mathrm{h})\end{array}$} & Average & 0.9 & 0.7 & 0.9 & 0.9 & 1 & 0.8 & 1.3 & 0.9 \\
\hline & Median & 1 & 1 & 1 & 1 & 1 & 1 & 1 & 1 \\
\hline \multirow{2}{*}{ Event peak flow } & u-test & \multirow{2}{*}{\multicolumn{2}{|c|}{$\begin{array}{l}0.19 \\
0.76\end{array}$}} & \multirow{2}{*}{\multicolumn{2}{|c|}{$\begin{array}{l}0.59 \\
0.19\end{array}$}} & \multirow{2}{*}{\multicolumn{2}{|c|}{$\begin{array}{l}0.26 \\
0.51\end{array}$}} & \multirow{2}{*}{\multicolumn{2}{|c|}{$\begin{array}{l}0.47 \\
0.18\end{array}$}} \\
\hline & ANCOVA test & & & & & & & & \\
\hline \multirow{2}{*}{ Event quick flow } & u-test & \multirow{2}{*}{\multicolumn{2}{|c|}{$\begin{array}{l}0.28 \\
0.14\end{array}$}} & \multirow{2}{*}{\multicolumn{2}{|c|}{$\begin{array}{l}0.59 \\
0.44\end{array}$}} & \multirow{2}{*}{\multicolumn{2}{|c|}{$\begin{array}{l}0.77 \\
0.87\end{array}$}} & \multirow{2}{*}{\multicolumn{2}{|c|}{$\begin{array}{l}0.15 \\
0.11\end{array}$}} \\
\hline & ANCOVA test & & & & & & & & \\
\hline \multirow{2}{*}{ Event water yield } & u-test & \multirow{2}{*}{\multicolumn{2}{|c|}{$\begin{array}{l}0.16 \\
0.83\end{array}$}} & \multirow{2}{*}{\multicolumn{2}{|c|}{$\begin{array}{l}0.27 \\
0.34\end{array}$}} & \multirow{2}{*}{\multicolumn{2}{|c|}{$\begin{array}{l}0.59 \\
0.93\end{array}$}} & & \\
\hline & ANCOVA test & & & & & & & & 24 \\
\hline $\begin{array}{l}\text { Event peak } \\
\text { response time }\end{array}$ & u-test & & & & 74 & & & & 48 \\
\hline
\end{tabular}

The event peak flow, the event quick flow, and the event water yield were all found to increase only for events with rainfall amount $\geq 30 \mathrm{~mm}$ and average rainfall intensity $\geq 2 \mathrm{~mm} / \mathrm{h}$ after thinning. However, as shown in the u-test in Table 1, no significant changes were found in the event peak flow, the event quick flow, or the event water yield for median values, before and after thinning in any group. The ANCOVA tests also showed no significant changes in the relationship between event peak 
flow, the event quick flow, and the event water yield with rainfall amount. Also, significant changes were not found in the event peak response time (Table 1).

No changes of rainfall-runoff characteristics during events were revealed after thinning of $50 \%$ in the YEC. For catchments with similar thinning percentages, Dung et al. [19] found thinning of $58.3 \%$ in a 0.35 ha steep headwater catchment $(0.70-1.00 \mathrm{~m} / \mathrm{m})$ did not affect event peak flow. In catchments with thinning percentages lower than 50\%, Rahman et al. [18] and Choi et al. [20] also reported no event peak flow changes after thinning. However, previous thinning studies only focused on event-based hydrographs. Only performing event flow analysis may omit important rainfall-runoff changes after thinning, particularly the flow peaks other than event peak flow. Therefore, apart from the aforementioned traditional analysis of event flow, we proposed an alternative analysis of flow peaks, taking all flow peaks during events into account, which provided a better linkage between rainfall and runoff characteristics.

\subsection{Flow Peaks Changes after Thinning}

To augment our study, we analyzed all flow peaks for all the events. There were 194 flow peaks for the 67 events before thinning, among which 49 events had multiple flow peaks, covering 127 flow peaks that were not event peak flow. Similarly, there were 184 flow peaks for the 64 events after thinning, among which 43 events had multiple flow peaks, covering 120 flow peaks that were not event peak flow (Figure 6). The average duration of the flow peaks changed from $10.9 \mathrm{~h}$ before thinning to $11.6 \mathrm{~h}$ after thinning. The recession time, which is the time it takes for the flow peak to decrease by the calculated flow drop, changed from $7.6 \mathrm{~h}$ to $8.2 \mathrm{~h}$.

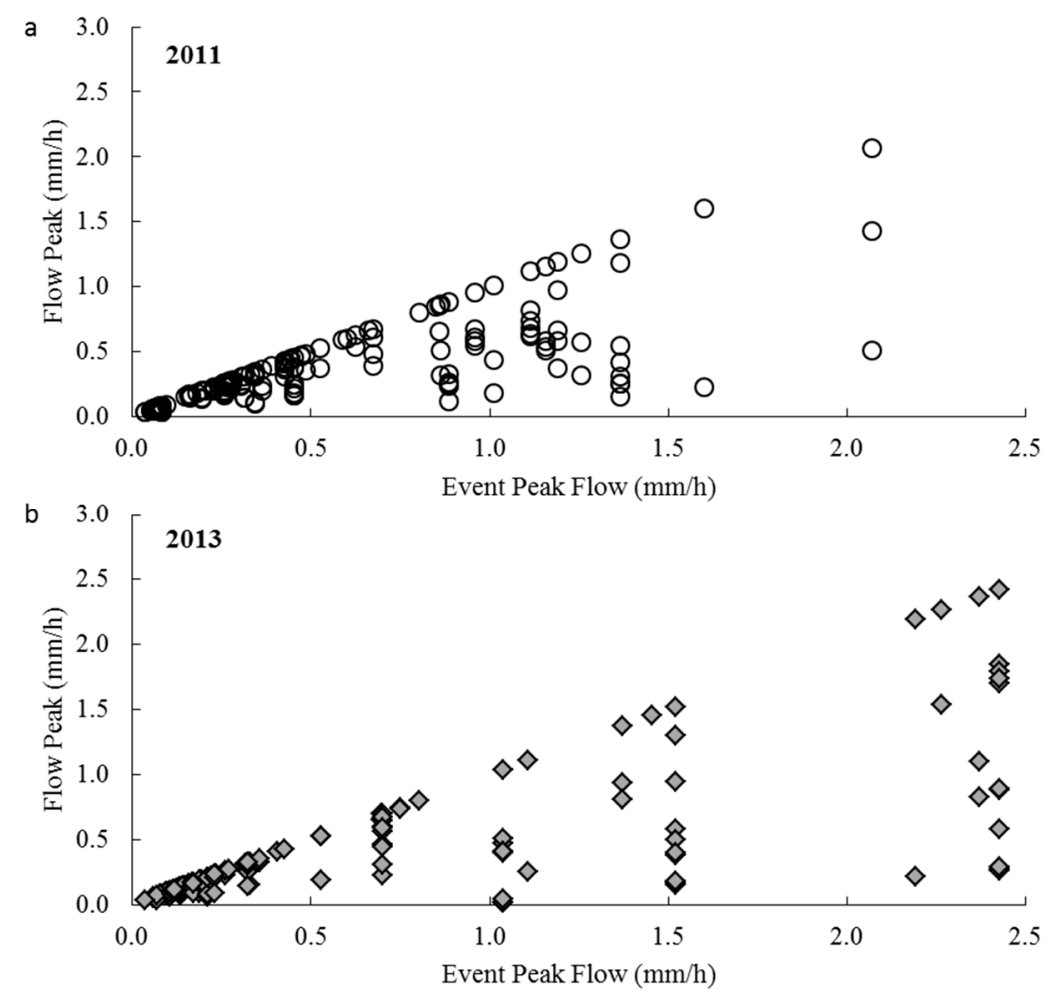

Figure 6. Event peak flow in relation to flow peak (a) 2011; (b) 2013.

The relationships of the accumulated rainfall with the flow peak, the accumulated quick flow, the flow rise, and the flow drop are illustrated in Figure 7. Our results indicate that the flow peak (ANCOVA: $p=0.30$ ) did not show any significant increases with accumulated rainfall (Figure 7a). However, the flow rise (ANCOVA: $p=0.01$ ), and the flow drop (ANCOVA: $p=0.02$ ) showed 
significant increases with accumulated rainfall after thinning (Figure $7 \mathrm{~b}, \mathrm{c}$ ). The accumulated quick flow (ANCOVA: $p=0.03$ ) also showed significant increases with accumulated rainfall after thinning (Figure 7d).

$\circ 2011 \diamond 2013$
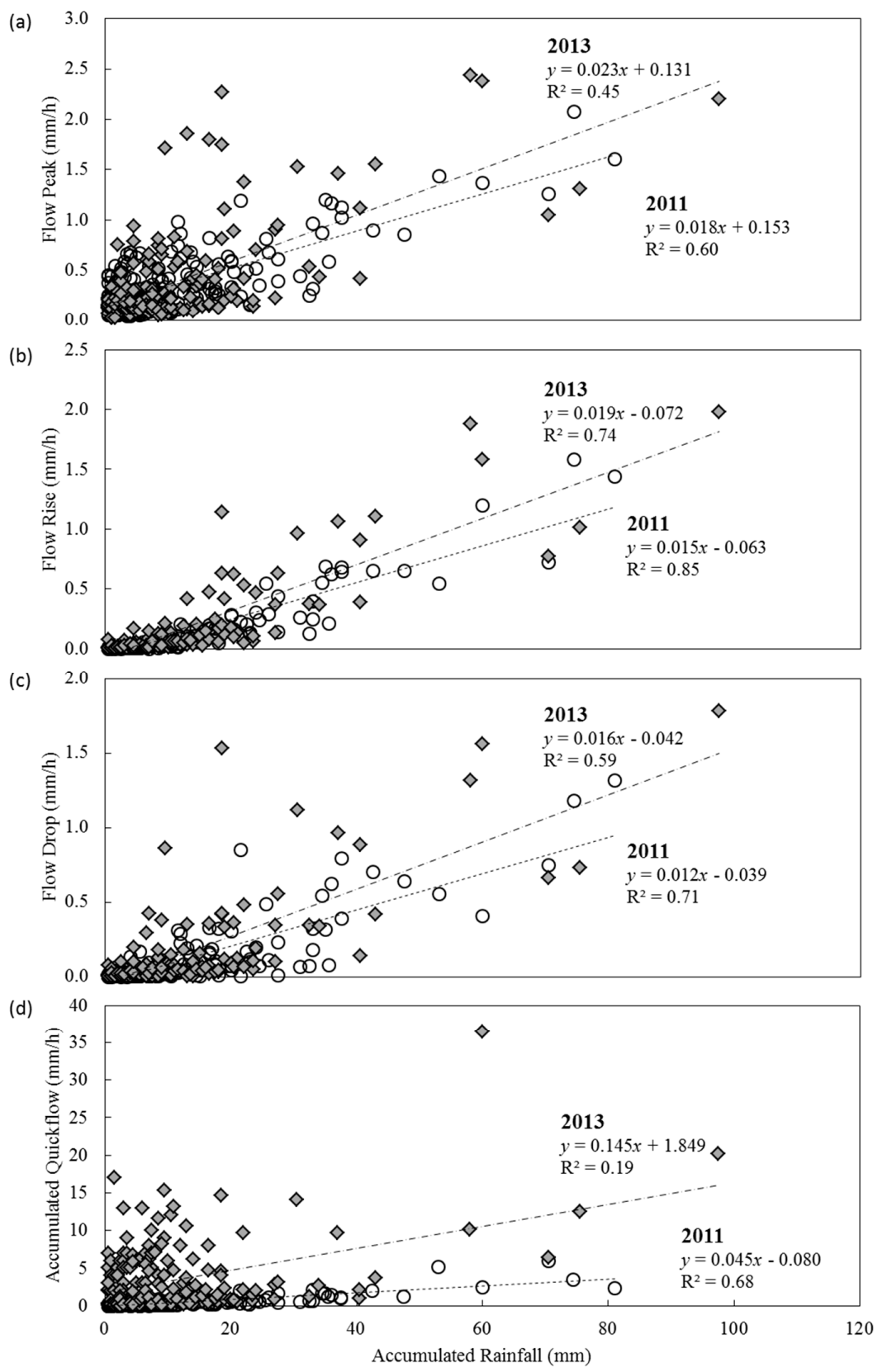

Figure 7. Accumulated rainfall in relation to (a) flow peak; (b) flow rise; (c) flow drop; (d) accumulated quick flow for all the flow peaks in 2011 and 2013.

In the YEC, the larger flow drop led to the lower initial flow of the subsequent peak, which resulted in no increase in the flow peak, despite the significant increase in flow rise after thinning (Figure 8). The larger flow rise and flow drop combined with the similar duration and magnitude of the flow peaks led to the larger accumulated quick flow after thinning (Figure 8).

To investigate the effects of thinning on flow peaks in detail, we grouped each flow peak, based on the same criteria used in the event flow analysis, i.e., a rainfall amount of $30 \mathrm{~mm}$, and an average 
rainfall intensity of $2 \mathrm{~mm} / \mathrm{h}$ (Table 2, Figure 9). The number of flow peaks and accumulated rainfall for each group were similar before and after thinning (Table 2, Figure 9a).
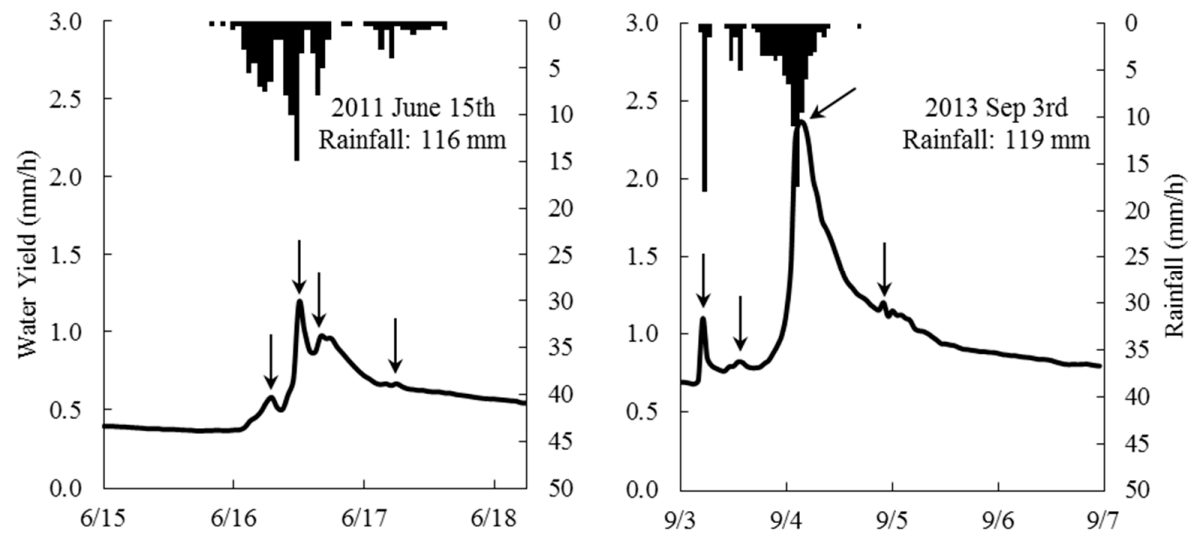

Figure 8. Hydrographs for typical events selected in 2011 (left) and 2013 (right); arrows indicate the selection of flow peaks.

Table 2. Summary of flow peaks characteristics in 2011 (Before) and 2013 (After); $p$-values are listed in the u-test and ANCOVA results section.

\begin{tabular}{|c|c|c|c|c|c|c|c|c|c|}
\hline \multirow{2}{*}{\multicolumn{2}{|c|}{$\begin{array}{c}\text { Rainfall Amount (mm) } \\
\text { Average Rainfall Intensity (mm/h) }\end{array}$}} & \multicolumn{4}{|c|}{$<30$} & \multicolumn{4}{|c|}{$\geq 30$} \\
\hline & & \multicolumn{2}{|c|}{$<2$} & \multicolumn{2}{|c|}{$\geq 2$} & \multicolumn{2}{|c|}{$<2$} & \multicolumn{2}{|c|}{$\geq 2$} \\
\hline \multicolumn{2}{|c|}{ Group Number } & \multicolumn{2}{|c|}{1} & \multicolumn{2}{|c|}{2} & \multicolumn{2}{|c|}{3} & \multicolumn{2}{|c|}{4} \\
\hline \multicolumn{2}{|c|}{ Years } & 2011 & 2013 & 2011 & 2013 & 2011 & 2013 & 2011 & 2013 \\
\hline \multicolumn{2}{|c|}{ Number of flow peaks } & 84 & 77 & 19 & 19 & 30 & 27 & 61 & 61 \\
\hline \multirow{2}{*}{$\begin{array}{l}\text { Accumulated } \\
\text { rainfall }(\mathrm{mm})\end{array}$} & Average & 4.1 & 4.5 & 11.1 & 10.7 & 7.9 & 8.2 & 20.9 & 18.9 \\
\hline & Median & 2.5 & 3.0 & 10.5 & 10.5 & 4.8 & 5.5 & 17.5 & 13.0 \\
\hline \multirow{2}{*}{ Flow peak $(\mathrm{mm} / \mathrm{h})$} & Average & 0.18 & 0.18 & 0.36 & 0.22 & 0.31 & 0.23 & 0.60 & 0.73 \\
\hline & Median & 0.16 & 0.13 & 0.31 & 0.20 & 0.33 & 0.12 & 0.51 & 0.53 \\
\hline \multirow{2}{*}{ Flow rise $(\mathrm{mm} / \mathrm{h})$} & Average & 0.02 & 0.02 & 0.09 & 0.07 & 0.04 & 0.05 & 0.25 & 0.33 \\
\hline & Median & 0.01 & 0.01 & 0.06 & 0.07 & 0.01 & 0.02 & 0.12 & 0.13 \\
\hline \multirow{2}{*}{ Flow drop $(\mathrm{mm} / \mathrm{h})$} & Average & 0.02 & 0.02 & 0.09 & 0.07 & 0.04 & 0.05 & 0.22 & 0.30 \\
\hline & Median & 0.01 & 0.01 & 0.06 & 0.07 & 0.01 & 0.02 & 0.08 & 0.09 \\
\hline \multirow{2}{*}{$\begin{array}{l}\text { Accumulated quick } \\
\text { flow }(\mathrm{mm})\end{array}$} & Average & 0.15 & 0.41 & 0.72 & 0.56 & 1.23 & 1.09 & 2.47 & 3.70 \\
\hline & Median & 0.09 & 0.17 & 0.40 & 0.31 & 0.74 & 0.48 & 1.29 & 1.48 \\
\hline \multirow{2}{*}{$\begin{array}{c}\text { Flow peak response } \\
\text { time }(\mathrm{h})\end{array}$} & Average & 0.9 & 0.6 & 0.8 & 0.7 & 0.6 & 0.5 & 1.0 & 0.4 \\
\hline & Median & 1.0 & 0.0 & 1.0 & 1.0 & 0.0 & 0.0 & 1.0 & 0.0 \\
\hline Accumulated rainfall & u-test & \multicolumn{2}{|c|}{0.67} & \multicolumn{2}{|c|}{0.95} & \multicolumn{2}{|c|}{0.51} & \multicolumn{2}{|c|}{0.35} \\
\hline \multirow{2}{*}{ Flow peak } & u-test & \multirow{2}{*}{\multicolumn{2}{|c|}{$\begin{array}{l}0.73 \\
0.94\end{array}$}} & \multicolumn{2}{|c|}{0.04} & \multicolumn{2}{|c|}{0.06} & \multicolumn{2}{|c|}{0.64} \\
\hline & ANCOVA test & & & & & & & & \\
\hline & u-test & \multicolumn{2}{|c|}{0.03} & \multicolumn{2}{|c|}{0.66} & & & & \\
\hline Flow rise & ANCOVA test & & & & & & & & \\
\hline Flow dron & u-test & & & & & & & & \\
\hline Flow arop & ANCOVA test & & & & & & & & \\
\hline Accumulated & u-test & & & & & & & & \\
\hline quick flow & ANCOVA test & & & & & & & & \\
\hline $\begin{array}{l}\text { Flow peak } \\
\text { response time }\end{array}$ & u-test & & & & & & & & \\
\hline
\end{tabular}




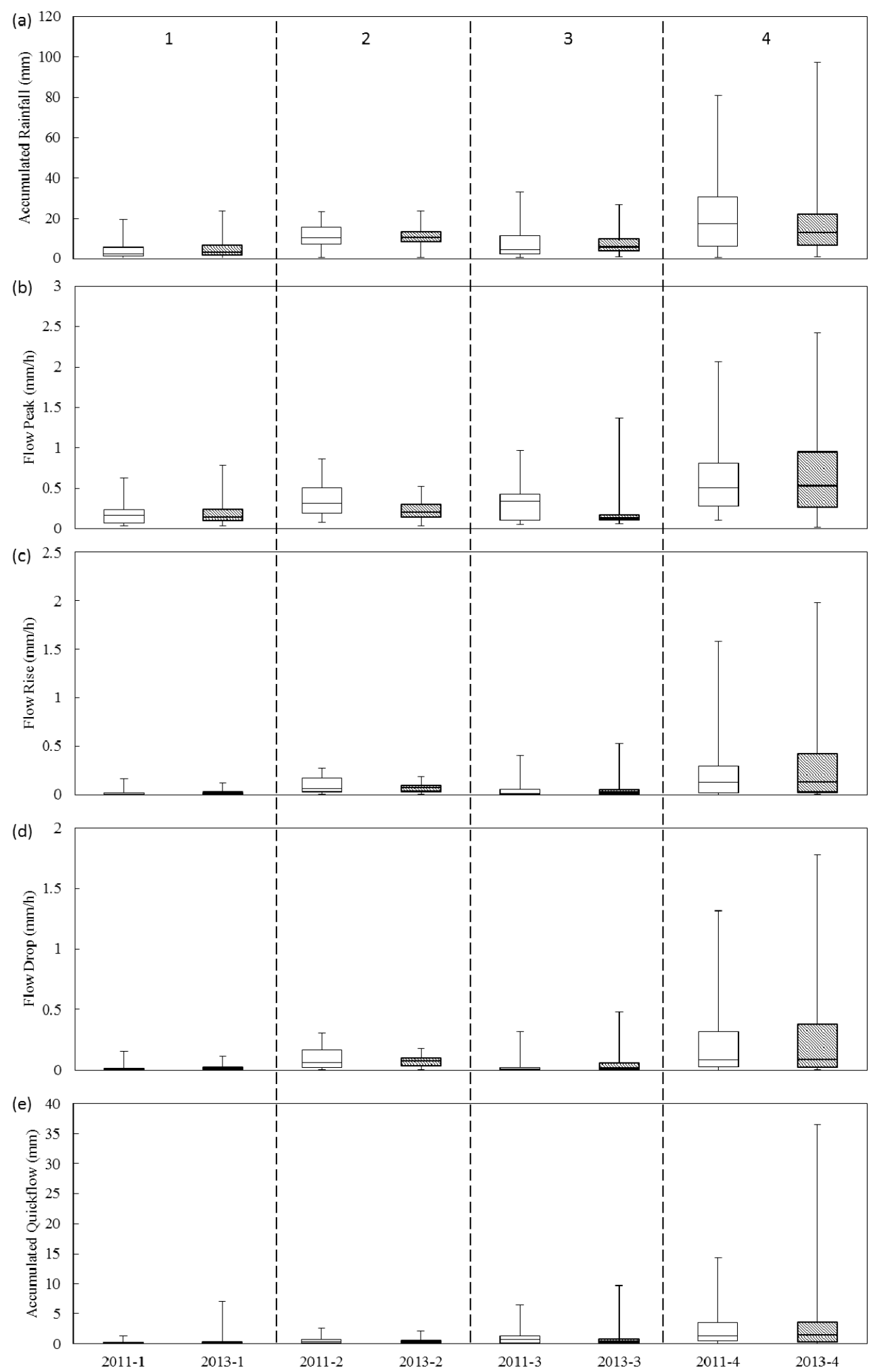

Figure 9. Box plot of (a) accumulated rainfall; (b) flow peak; (c) flow rise; (d) flow drop; (e) accumulated quick flow for each group of flow peaks in 2011 (blank box) and 2013 (shaded box). The horizontal line within the box indicates the median, boundaries of the box indicate the 25th- and 75th-percentile, the whiskers indicate the highest and lowest values of the results and dashed lines are for group divisions. 
In group 4, large increases were found for all averages and medians of flow peak, flow rise, flow drop, and accumulated quick flow (Table 2, Figure 9). In groups 1, 2 and 3, the average and median of each parameter changed, although changes were small (Figure 9). The average flow peak response time decreased in all groups. Flow peak, flow rise, flow drop, and accumulated quick flow in group 4 showed a significant increase. Accumulated quick flow in group 1 showed a significant increase. Flow peak in group 2 showed a significant decrease, although the sample size is small. Flow peak response time in groups 1 and 4 showed significant decreases after thinning (Table 2).

\subsection{Comparisons of Event Flow and Flow Peaks}

Although no changes in the event peak flow, event quick flow, and event peak response time were found before and after thinning in our event flow analysis, changes were revealed in the flow rise, flow drop, accumulated quick flow and flow peak response time after thinning using a flow peak analysis. The flow peaks show a more direct link between rainfall and runoff, and the changes observed in the characteristics of these flow peaks suggest that the rainfall-runoff characteristics changed after thinning. In particular, we found significant changes in flow peak characteristics of group 1 and group 4 .

In group 1, the flow rise increased and the flow peak response time was shortened after thinning (Table 2, Figure 9). Although previous studies have not focused on a flow peak analysis, in event-based studies, relative interception loss (the ratio of interception to rainfall) would be high during events with a small rainfall amount [36,37]. Leaf area index (LAI) was measured in a Japanese cypress plot and a Japanese cedar plot before and after thinning. During events having less than $10 \mathrm{~mm}$ accumulated rainfall in the YEC, the closed canopy before thinning (LAI $=3.80 \mathrm{~m}^{2} \mathrm{~m}^{-2}$ in the Japanese cypress plot and LAI $=3.50 \mathrm{~m}^{2} \mathrm{~m}^{-2}$ in the Japanese cedar plot) could intercept more rainwater than the sparse canopy after thinning (LAI $=0.77 \mathrm{~m}^{2} \mathrm{~m}^{-2}$ in the Japanese cypress plot and LAI $=0.84 \mathrm{~m}^{2} \mathrm{~m}^{-2}$ in the Japanese cedar plot) [30]. The increased throughfall after thinning indicates that more water reaches the forest floor, and contributes to runoff, which may lead to a larger flow rise and a quicker catchment runoff response.

In group 4, the flow peaks exhibited a significant increase in flow peak, flow rise, flow drop and accumulated quick flow (Table 2, Figure 9). During intense rainfall after thinning, the rapid increase and decrease in flow indicates that the catchment exhibited more shallow flow paths. Based on event scale analysis, canopy interceptions were measured in the YEC and found to decrease from $23.1 \%$ to $22.4 \%$ in the Japanese cypress plot and from $27.2 \%$ to $21.5 \%$ in the Japanese cedar plot, after thinning [38]. The decreased interception after thinning caused more throughfall. In the YEC, during large accumulated rainfall events, the saturated area extends to the hillslope, while the shallow groundwater in the riparian area reacts quickly to rainfall [39]. The contribution of extra water from throughfall after thinning may allow shallow riparian groundwater to generate more throughflow, causing the rapid increase and decrease of flow observed at this site. In a small forested catchment in Western Australia, throughflow from perched shallow groundwater increased after thinning, which led to the increase in event peak flow [16].

Previous studies examined the effect of thinning on rainfall-runoff processes using only event-based hydrographs; some studies showed no changes after thinning [19,20,40]. This study also showed no changes after thinning, when event-based hydrographs were analyzed. However, we observed significant changes in flow peaks. Thus, thinning affected the rainfall-runoff processes in the YEC, suggesting the importance of considering all flow peaks, especially in headwater catchments. Further investigation of the changes in flow peaks in studies dealing with the effects of thinning may reveal changes in rainfall-runoff processes that might not be detected in an event-based analysis. In future studies, multi-year comparisons of flow peak characteristics should be carried out.

\section{Conclusions}

Thinning of tree numbers by $50 \%$ was performed in the YEC, a steep headwater catchment in Japan, covered with 46-year-old Japanese cypress and cedar. Changes in rainfall-runoff characteristics 
were examined in the year prior to and after thinning. Event based analysis did not reveal any significant changes after thinning. To capture the effects of thinning on rainfall-runoff characteristics more effectively, we examined all the flow peaks for all rainfall events. Increases in the accumulated quick flow, flow rise, and flow drop were detected for these events. The flow drop during the falling limb of each flow peak increased, and led to a lower initial flow in the subsequent peak, which yielded no increase in the flow peaks. The changes in rainfall-runoff characteristics were more prominent during flow peaks in events with over $30 \mathrm{~mm}$ rainfall amount and over two millimeter per hour average rainfall intensity. After thinning of the 46-year-old cypress and cedar tree plantation, the catchment exhibited more shallow flow paths during large rainfall events. These changes may induce higher flood risk and soil erosion during early post-thinning years. Further study, assessing the combined effects of understory vegetation and flow peak changes on flood risk and erosion problems needs to be carried out to evaluate these risks.

Acknowledgments: This study was supported by the Japan Science and Technology Agency (JST), the Core Research for Evolutional Science and Technology (CREST) project entitled “Development of innovative technologies for increasing catchment runoff and improving river environments by the developing management practices for devastated forest plantations", Fukuoka Prefecture Foundation for Headwater Forests and JSPS KAKENHI Grant (Adjustment of stand density control diagram for water resource conservation) Number 26292088. We acknowledge Sodouangdenh Somsanouk, Xiang Yang, Hun Sothy, Hiroki Matsuda, Shuji Yunohara, and Misako Komatsu in Kyushu University for their support in the field data collection. We are grateful to Masayoshi Watanabe in Kahanzan forest owner's corporative for the thinning operation.

Author Contributions: Sun H. developed the flow peak analysis method and wrote the manuscript. Otsuki K. and Kasahara T. aided in the conception of the methodology for data development. Onda Y. designed the project. Tateishi M. and Saito T. aided in the field measurement and data collection.

Conflicts of Interest: The authors declare no conflict of interest.

\section{References}

1. National Astronomical Observatory. Chronological Environmental Tables MMIX/2010; Maruzen: Tokyo, Japan, 2009; p. 98. (In Japanese)

2. Japan Forestry Agency. Forest White Paper; Japan Forestry Agency: Tokyo, Japan, 2007; p. 165. (In Japanese)

3. Onda, Y. Current Status of Discharge and Sediment Runoff in Abandoned Plantation Forests; Iwanami Shoten: Tokyo, Japan, 2010. (In Japanese)

4. Miura, S.; Hirai, K.; Yamada, T. Transport rates of surface materials on steep forested slopes induced by raindrop splash erosion. J. For. Res. 2002, 7, 201-211. [CrossRef]

5. Nanko, K.; Mizugaki, S.; Onda, Y. Estimation of soil splash detachment rates on the forest floor of an unmanaged Japanese cypress plantation based on field measurements of throughfall drop sizes and velocities. Catena 2008, 3, 348-361. [CrossRef]

6. Gomi, T.; Asano, Y.; Uchida, T.; Onda, Y.; Sidle, R.C.; Miyata, S.; Kosugi, K.; Mizugaki, S.; Fukuyama, T.; Fukushima, T. Evaluation of storm runoff pathways in steep nested catchments draining a Japanese cypress forest in central Japan: A geochemical approach. Hydrol. Process. 2010, 24, 550-566. [CrossRef]

7. Sidle, R.C.; Hirano, T.; Gomi, T.; Terajima, T. Hortonian overland flow from Japanese forest plantations-An aberration, the real thing, or something in between? Hydrol. Process. 2007, 21, 3237-3247. [CrossRef]

8. Lesch, W.; Scott, D.F. The response in water yield to the thinning of Pinus radiata, Pinus patula and Eucalyptus grandis plantations. Forest. Ecol. Manag. 1997, 99, 295-307. [CrossRef]

9. Yanai, R.D.; Twery, M.J.; Stout, S.L. Woody understory response to changes in overstory density: Thinning in Allegheny hardwoods. For. Ecol. Manag. 1998, 102, 45-60. [CrossRef]

10. Grace, J.M., III; Skaggs, R.M.; Cassel, D.K. Soil physical changes associated with forest harvesting operations on an organic soil. Soil Sci. Soc. Am. J. 2006, 70, 503-509. [CrossRef]

11. Bosch, J.M.; Hewlett, J.D. A review of catchment experiments to determine the effect of vegetation changes on water yield and evapo-transpiration. J. Hydrol. 1982, 55, 3-23. [CrossRef]

12. Hornbeck, J.W.; Adams, M.B.; Corbett, E.S.; Verry, E.S.; Lynch, J.A. Long-term impacts of forest treatments on water yield: A summary for northeastern USA. J. Hydrol. 1993, 150, 323-344. [CrossRef] 
13. Stednick, J.D. Monitoring the effects of timber harvest on annual water yield. J. Hydrol. 1996, 176, 79-95. [CrossRef]

14. Andréassian, V. Waters and forests: From historical controversy to scientific debate. J. Hydrol. 2004, $291,1-27$. [CrossRef]

15. Wright, K.A.; Sendek, K.H.; Rice, R.M.; Thomas, R.B. Logging effects on streamflow: Storm runoff at Caspar Creek in northwestern California. Water Resour. Res. 1990, 26, 1657-1667. [CrossRef]

16. Ruprecht, J.K.; Schofield, N.J.; Crombie, D.S.; Vertessy, R.A.; Stoneman, G.L. Early hydrological response to intense forest thinning in southwestern Australia. J. Hydrol. 1991, 127, 261-277. [CrossRef]

17. Grace, J.M., III; Skaggs, R.W.; Malcom, H.R.; Chescheir, G.M.; Cassel, D.K. Influence of Thinning Operations on the Hydrology of a Drained Coastal Plantation Watershed; Paper Number 032038; The Society of Engineering in Agricultural, Food, and Biological Systems: Las Vegas, NV, USA, 2003. [CrossRef]

18. Rahman, A.A.; Hiura, H.; Shino, K.; Takese, K. Effects of forest thinning on direct runoff and peak runoff properties in a small mountainous watershed in Kochi Prefecture, Japan. Pak. J. Biol. Sci. 2005, 8, 259-266. [CrossRef]

19. Dung, B.X.; Gomi, T.; Miyata, S.; Sidle, R.C.; Kosugi, K.; Onda, Y. Runoff responses to forest thinning at plot and catchment scales in a headwater catchment draining Japanese cypress forest. J. Hydrol. 2012, 444-445, 51-62. [CrossRef]

20. Choi, B.; Hatten, J.A.; Dewey, J.C.; Otsuki, K.; Cha, D. Effect of timber harvesting on stormflow characteristics in headwater streams of managed, forested watersheds in the Upper Gulf Coastal Plain in Mississippi. J. Fac. Agric. Kyushu. Univ. 2013, 58, 395-402.

21. Ziemer, R.R. Storm flow response to road building and partial cutting in small streams of northern California. Water Resour. Res. 1981, 17, 907-917. [CrossRef]

22. Sendek, K.H. Effects of Timber Harvesting on the Lag Time of Caspar Creek Watershed. Master's Thesis, Humboldt State University, Arcata, CA, USA, 1985.

23. McGlynn, B.L.; McDonnell, J.J.; Seibert, J.; Kendall, C. Scale effects on headwater catchment runoff timing, flow sources, and groundwater-streamflow relations. Water Resour. Res. 2004, 40, W07504. [CrossRef]

24. Davies, J.A.C.; Beven, K. Hysteresis and scale in catchment storage, flow and transport. Hydrol. Process. 2015, 29, 3604-3615. [CrossRef]

25. Warburton, J. Sediment transfer in steep upland catchments (northern England, UK): Landform and sediment source coupling. In Landform-Structure, Evolution, Process Control; Otto, J.C., Dikau, R., Eds.; Springer: Berlin, Germany, 2010; pp. 165-183. [CrossRef]

26. Alexander, R.B.; Boyer, E.W.; Smith, R.A.; Schwarz, G.E.; Moore, R.B. The role of headwater streams in downstream water quality. J. Am. Water. Resour. Assoc. 2007, 43, 41-59. [CrossRef] [PubMed]

27. Beschta, R.L.; Platts, W.S. Morphological Features of Small Streams: Significance and Function. J. Am. Water Resour. Assoc. 1986, 22, 369-379. [CrossRef]

28. Abansu Corporation. Report of Well Construction; Abansu Corp.: Kumamoto, Japan, 2010. (In Japanese)

29. Takahashi, J. Development of innovative technologies for increasing catchment runoff and improving river environments by the developing management practices for devastated forest plantations. 2014; unpublished.

30. Tateishi, M.; Xiang, Y.; Saito, T.; Otsuki, K.; Kasahara, T. Changes in canopy transpiration of Japanese cypress and Japanese cedar plantations because of selective thinning. Hydrol. Process. 2015, 29, 5088-5097. [CrossRef]

31. Eckhardt, K. How to construct recursive digital filters for baseflow separation. Hydrol. Process. 2005, 19, 507-515. [CrossRef]

32. Collischonn, W.; Fan, F.M. Defining parameters for Eckhardt's digital baseflow filter. Hydrol. Process. 2013, 27, 2614-2622. [CrossRef]

33. Gonzales, A.L.; Nonner, J.; Heijkers, J.; Uhlenbrook, S. Comparison of different base flow separation methods in a lowland catchment. Hydrol. Earth Syst. Sci. 2009, 13, 2055-2068. [CrossRef]

34. Lim, K.J.; Park, Y.S.; Kim, J.; Shin, Y.-C.; Kim, N.W.; Kim, S.J.; Jeon, J.-H.; Engel, B.A. Development of genetic algorithm-based optimization module in WHAT system for hydrograph analysis and model application. Comput. Geosci. 2010, 36, 936-944. [CrossRef]

35. Wilks, D. Statistical Methods in the Atmospheric Sciences, 3rd ed.; Academic Press: Cambridge, MA, USA, 2011; Volume 100

36. Ward, R.C.; Robinson, M. Principles of Hydrology; McGraw-Hill: London, UK, 2010. 
37. Xiao, Q.; McPherson, E.G.; Ustin, S.L.; Grismer, M.E.; Simpson, J.R. Winter rainfall interception by two mature open-grown trees in Davis, California. Hydrol. Process. 2000, 14, 763-784. [CrossRef]

38. Matsuda, H. Canopy Interception and Spatial Variation of Throughfall in Japanese Cedar and Cypress Plantation. Master's Thesis, Kyushu University, Fukuoka, Japan, 2013.

39. Sun, H.; Kasahara, T.; Otsuki, K.; Saito, T.; Onda, Y. Spatio-temporal streamflow generation in a small, steep headwater catchment in western Japan. Hydrol. Sci. J. 2016, 1-12. [CrossRef]

40. Dung, B.X.; Gomi, T.; Miyata, S.; Sidle, R.C. Peak flow responses and recession flow characteristics after thinning of Japanese cypress forest in a headwater catchment. Hydrol. Res. Lett. 2012, 6, 35-40. [CrossRef]

(C) 2017 by the authors. Licensee MDPI, Basel, Switzerland. This article is an open access article distributed under the terms and conditions of the Creative Commons Attribution (CC BY) license (http://creativecommons.org/licenses/by/4.0/). 